\title{
Generic Determinant of Entrepreneurial Potentials among Vocational Technical Teacher Education Students in North Eastern States, Nigeria
}

\author{
M. U Cyril \\ Department of Technical Education, Modibbo Adama University of Technology, Yola, Nigeria
}

\begin{abstract}
Entrepreneurs can be made when individuals imbibe entrepreneurial traits through training in technical and vocational Education (TVET). The Nigerian perspective seems to encourage the teaching of entrepreneurship education at peripheral level. This paper posits differently. The purpose of the study was to find out the determinants of entrepreneurial potentials among vocational technical teacher education students in North eastern states of Nigeria. The population of the study was 766 while, the sample was 497. A non dichotomous structured questionnaire was subjected to validation. The reliability of the internal consistency yielded 0.89 using the alpha method. The methods of analysis used include mean, standard deviation and analysis of variance. The respondents differ significantly on the general characteristics that determine entrepreneurial potentials. Thus a post-hoc test was conducted using Turkey Honestly Significant Difference which revealed that the difference was from students' weaknesses in identifying the personality potentials that foster entrepreneurial traits. One of the major findings was that ability to work extra hours was considered as an undesirable trait for potential entrepreneur which induced stressors.
\end{abstract}

Keywords: Generic, Determinant, Entrepreneurial

\section{Introduction}

Entrepreneurship education has started developing steadily but unevenly in most countries around the world and this has impact on economic and human behaviour. According to Fayolle and Lyon (2004) entrepreneurship combined with training influence both current behaviour and future intentions of vocational technical teacher education (VTTE) students. In other words, there are great differences between students who have taken entrepreneurship education programme and those who have not. The National University Commission Abuja, Nigeria (NUC) in 2009 mandated all tertiary institutions in Nigeria to offer entrepreneurship education as a course. This ideal was quite noble at the inception but runs the risk of producing graduates who are yet to possess the required competencies in entrepreneurship education. Entrepreneurship education should not be taught at peripheral level but rather as a full programme for proliferation of pure entrepreneurs. Nevertheless, Carolyn (2000) viewed entrepreneurship education in terms of the skills that can be taught and characteristics that can be engendered in students which can help them to develop new and innovative plans. Individuals are widely recognized as the primary agents of entrepreneurial activity. Since the origin of any innovation, start-up or entrepreneurial decision is traceable to a single person; one approach to fostering entrepreneurship in higher vocational technical education programme is to strengthen the entrepreneurial traits in the individuals (McClelland 1961 \& Casson, 2003). McClelland further emphasized the importance of the motivational aspect of the entrepreneur and showed that entrepreneurial behaviour is driven by the need for personal achievement leading to a clear productivity for becoming an entrepreneur. A potential entrepreneur is one who, taking into account his judgment, would accept to bear the uncertainty of production and trade whose expected profit would be payment for this specific activity. Individuals are not different in their attitude towards risk, but in their competence, intelligence, creative capacities and valuable traits that are corresponding to a wide range of skills such as talents in an entrepreneurial project (Jovanovic, 1994). Conversely, Dejardin (2000) asserted that what characterizes an entrepreneur is not a particular ability to bear the consequences of unforeseeable events but undertaking economic activities and innovating required skills that make the entrepreneur a person of exception and one whose one of his motives continues to be profit seeking.

Nel and Badenhorst (2003) observed that personality traits such as initiative and independent spirit make individuals to find alternative ways of earning a living for themselves. These qualities are appropriate for vocational technical education students who are expected to be self employed after graduation. When people acquire skills especially in the ability to take decision, make commitment, take risk, motivate, solve financial problems, understand family situations, be self confident, radiate energy and drive, generate task orientation, leadership and personal responsibilities that are very important in the life of a potential entrepreneur they would be able to establish enterprises and manage them well (Lynch, 2000 \& Johnson, 2003). Individuals who manifest these qualities can assess whether a person can be a successful entrepreneur. It can be inferred that when vocational technical teacher education students are fully equipped to exploit their personality traits then there will be assurance that they will be self employed after graduation. This is because they would have become competent enough to visualize and recognize employment opportunity. These traits are the qualities a teacher should encourage in higher vocational technical education students for them to be able to start up an enterprise after graduation. In this study, vocational technical teacher education students are students who offer VTTE programme in tertiary institution in Nigeria. Such students are expected to either take teaching as a profession or work in the industry. 


\section{International Journal of Science and Research (IJSR) \\ ISSN (Online): 2319-7064 \\ Index Copernicus Value (2013): 6.14 | Impact Factor (2014): 5.611}

Therefore an attempt was made to determine what constitute entrepreneurial potentials among VTTE students. The question the study sought to answer is: what are the common characteristics of potential entrepreneur that could stimulate VTTE students into job creation?

\section{Hypothesis of the Study}

The following null hypothesis was tested at 0.05 level of statistical significance:

Ho $_{1}$ : There is no significant difference in the mean responses of entrepreneurs, vocational technical teachers and students on the general characteristics that determine entrepreneurial potential.

\section{Methodology}

The research design for this study was a survey and the geographical area in which this study was carried out is the North Eastern states of Nigeria comprising of Borno, Gombe, Taraba and Yobe. The population for the study was 766 which consisted of 156 vocational technical teachers, 68 industrial entrepreneurs and 542 final year students in federal and state owned colleges of education in North Eastern states, Nigeria where vocational technical education programme is offered. The sample for the study was 497. Five colleges of education were used for the study. One institution from each state was used. However, two institutions were selected from Borno state which has two colleges of education offering VTTE programme.

The proportionate sampling technique was used to select $50 \%$ from the number of final year vocational technical teacher education students in each of the colleges identified to make up 273 students. All of the 156 vocational technical teachers and all the 68 industrial entrepreneurs were used for the study. A 31 item structured questionnaire with a five point rating scale was constructed for the study which requested the respondents to indicate what constitute

Table 1: Mean Responses of Entrepreneurs, Vocational Technical Teachers and VTTE students on the General Characteristics that Determine Potential Entrepreneur.

\begin{tabular}{|c|c|c|c|c|c|c|c|}
\hline & $\begin{array}{l}\text { Characteristics that indicate Entrepreneurial } \\
\text { Potentials: Ability to, }\end{array}$ & $\overline{\mathbf{X}}_{\mathbf{E}}$ & $\overline{\mathbf{X}}_{\mathbf{T}}$ & $\overline{\mathbf{X}}_{\mathrm{S}}$ & $\overline{\mathbf{X}}_{\text {Grand }}$ & $\mathbf{S}$ & Remark \\
\hline 1. & Recognize business opportunities & 4.38 & 4.44 & 4.53 & 4.45 & 0.65 & Desirable \\
\hline 2. & Be able to initiate ideas & 4.34 & 4.38 & 4.39 & 4.37 & 0.74 & Desirable \\
\hline 3. & Demand for efficiency and quality & 4.38 & 4.32 & 4.16 & 4.29 & 0.76 & Desirable \\
\hline 4. & Set appropriate goals for enterprise & 4.38 & 4.35 & 4.31 & 4.35 & 0.77 & Desirable \\
\hline 5. & Be persistent in pursuing set objectives & 4.18 & 4.29 & 4.04 & 4.17 & 0.86 & Desirable \\
\hline 6. & Be persuasive and networking & 4.04 & 4.16 & 4.05 & 4.08 & 0.84 & Desirable \\
\hline 7. & Take reasonable risks & 3.84 & 3.95 & 3.62 & 3.80 & 1.03 & Desirable \\
\hline 8. & Take charge in any business venture & 3.94 & 3.92 & 3.97 & 3.94 & 0.98 & Desirable \\
\hline 9. & Get along well with others & 4.31 & 4.19 & 4.11 & 4.20 & 0.82 & Desirable \\
\hline 10. & Take decisions promptly & 4.12 & 4.11 & 4.14 & 4.12 & 0.92 & Desirable \\
\hline 11. & Accept responsibility for one's actions & 3.94 & 4.17 & 3.84 & 3.98 & 0.97 & Desirable \\
\hline 12. & Cultivate competitive spirit & 4.12 & 4.25 & 3.88 & 4.08 & 0.96 & Desirable \\
\hline 13. & Accept full responsibility for success or failure & 4.26 & 4.23 & 4.04 & 4.18 & 0.87 & Desirable \\
\hline 14. & Demonstrate self confidence & 4.22 & 4.42 & 4.29 & 4.31 & 0.75 & Desirable \\
\hline 15. & Be able to deal with negative trends or loses & 4.22 & 4.19 & 3.96 & 4.12 & 0.82 & Desirable \\
\hline 16. & Adapt to changing situations & 4.32 & 4.26 & 4.06 & 4.21 & 0.84 & Desirable \\
\hline 17. & Be innovative (do things in new ways) & 4.46 & 4.36 & 4.23 & 4.35 & 0.76 & Desirable \\
\hline 18. & Judge the abilities and skills of others & 4.18 & 4.19 & 3.95 & 4.11 & 0.90 & Desirable \\
\hline 19. & Save profit for expansion & 4.31 & 4.26 & 4.45 & 4.34 & 0.82 & Desirable \\
\hline 20. & Take independent actions & 3.91 & 3.91 & 4.03 & 3.95 & 0.98 & Desirable \\
\hline 21. & Demonstrate the drive to achieve & 3.99 & 4.21 & 4.17 & 4.12 & 0.87 & Desirable \\
\hline 22. & Motivate others to achieve & 4.25 & 4.28 & 4.27 & 4.27 & 0.87 & Desirable \\
\hline
\end{tabular}




\section{International Journal of Science and Research (IJSR) \\ ISSN (Online): 2319-7064}

Index Copernicus Value (2013): 6.14 | Impact Factor (2014): 5.611

\begin{tabular}{|r|c|c|c|c|c|c|c|}
\hline 23. & Demonstrate will power and self discipline & 4.29 & 4.19 & 4.13 & 4.20 & 0.84 & Desirable \\
\hline 24. & Demonstrate resourcefulness in business & 4.22 & 4.32 & 4.07 & 4.20 & 0.81 & Desirable \\
\hline 25. & Maintain high level of integrity & 4.41 & 4.43 & 4.25 & 4.36 & 0.81 & Desirable \\
\hline 26. & Be able to work under pressure & 4.21 & 4.21 & 3.90 & 4.11 & 0.97 & Desirable \\
\hline 27. & Become future oriented & 4.24 & 4.31 & 4.20 & 4.25 & 0.81 & Desirable \\
\hline 28. & Be hard working & 4.50 & 4.46 & 4.31 & 4.42 & 0.76 & Desirable \\
\hline 29. & Accept and face challenges & 4.40 & 4.42 & 4.18 & 4.33 & 0.80 & Desirable \\
\hline 30. & Work extra hours always & 2.01 & 2.22 & 2.36 & 2.20 & 0.88 & Undesirable \\
\hline 31. & Demonstrate imaginative and creative ideas & 4.37 & 4.19 & 4.19 & 4.25 & 0.86 & Desirable \\
\hline
\end{tabular}

$\overline{\mathrm{X}}_{\mathrm{E}}$ : Mean of entrepreneur, $\overline{\mathrm{X}}_{\mathrm{T}}$ : Mean of Teacher, $\overline{\mathrm{X}}_{\mathrm{S}}$ : Mean of Student.

Table 1 shows that item 30 with the lowest grand mean of 2.20 was below the decision point of 2.50. Thus, the ability to work extra hours always was considered by the respondents as an undesirable character which is not a general determinant of entrepreneurial potentials. However, the remaining 30 items were rated as desirable.

Hypothesis 1: There is no significant difference in the mean responses of entrepreneurs, vocational teachers and students on the general characteristics that determine potential entrepreneur $(\mathrm{p}<0.05$ level).

Table 2: Analysis of Variance Result comparing Responses of Entrepreneurs, Vocational Technical Teachers and Students on the General Characteristics that Determine Potential Entrepreneur

\begin{tabular}{|c|c|c|c|c|c|}
\hline Source of Variance & $\begin{array}{c}\text { Sum of } \\
\text { Squares }\end{array}$ & $\begin{array}{c}\text { Degree of } \\
\text { Freedom }\end{array}$ & $\begin{array}{c}\text { Mean } \\
\text { Square }\end{array}$ & F & Remark \\
\hline PPAT Between groups & 1.83 & 2 & 0.92 & 4.82 & S \\
\hline Within groups & 93.01 & 489 & 0.19 & & \\
\hline Total & 94.84 & 491 & & & \\
\hline
\end{tabular}

PPAT = Personality Potential Ability Traits $\mathrm{df}_{1}=2$

Level of significance $=0.05 \mathrm{df}_{2}=489$

$\mathrm{S}=$ Significant $\mathrm{F}$ critical $=2.99$

The calculated $F$ ratio in table 2 shows a value of 4.82 while the critical value of $F$ is 2.99. Thus the calculated $F$ is greater than the $\mathrm{F}$ critical. The null hypothesis is therefore rejected. This further indicates the differences in the mean responses of the respondents are significant and not as a result of chance. Although the mean responses of the three groups differ significantly, ANOVA does not indicate where these differences occur. Therefore a post hoc test was conducted using the Turkey Honestly Significant Difference (THSD) test. The Turkey test is appropriate where comparisons among means are to be made. SPSS Version 15 provides Post Hoc Test as part of the ANOVA.

The data used for the Turkey Honestly significant difference was obtained from the print out of the computer results of the ANOVA test. The following are the group identities:

Group 1 - Teachers, Group 2 - Entrepreneurs, Group 3Students.

\section{Multiple Comparisons}

\begin{tabular}{|l|c|c|c|c|}
\hline & Paring Groups & Mean Diff & Std Error & Sig \\
\hline Group 1 \& 2 & Teachers and Entrepreneurs & 0.02 & 0.06 & 0.94 \\
\hline Group 1 \& 3 & Teachers and Students & 0.13 & 0.44 & $0.01 *$ \\
\hline Group 2 \& 1 & Entrepreneurs and Teachers & -0.02 & 0.06 & 0.94 \\
\hline Group 2 \& 3 & Entrepreneurs and Students & 0.11 & 0.05 & 0.16 \\
\hline Group 3 \& 1 & Students and Teachers & -0.13 & 0.04 & 0.11 \\
\hline Group 3 \& 2 & Students and Entrepreneurs & -0.11 & 0.05 & 0.16 \\
\hline
\end{tabular}

*The mean difference is significant at 0.05 level.
The result above indicates that pair group ( $1 \& 3$, Teachers and students) recorded significant difference. The remaining pair groups did not record any significant difference. However, the group means responsible for the difference in pair group $1 \& 3$ is group 3 , which are students. When Teachers \& Entrepreneurs and students \& Entrepreneurs were paired, there was no significant difference in mean but when Teachers and Students were paired, there was a great significant difference. Perhaps the difference might have occurred due to the in ability of the students to identify properly the psychological traits that could manifest in entrepreneurial potential. Teachers and Entrepreneurs are already conversant with most of the personality potentials identified as a result of their experiences.

\section{Findings of the Study}

The following are the major findings of the study:

1) Thirty general characteristics that determine entrepreneurial potentials were considered as desirable which are:

i. $\quad$ Be able to initiate ideas

ii. Demand for efficiency and quality

iii. Set appropriate goals for enterprise

iv. Be persistent in pursuing set objectives

v. Be persuasive and networking

vi. Take charge in any business venture

vii. Accept responsibility for one's actions

viii. Accept full responsibility for success or failure

ix. Be able to deal with negative trends or loss

$\mathrm{x}$. Be innovative (do things in new ways)

xi. Judge the abilities and skills of others

xii. Demonstrate will power and self discipline

xiii. Demonstrate resource fullness in business

xiv. Maintain high level of integrity

xv. Demonstrate imaginative and creative ideas

xvi. Take reasonable risk

xvii. Get along well with others

xviii. Take decisions promptly

xix. Cultivate competitive spirit

xx. Demonstrate self confidence

xxi. Adapt the changing situations

xxii. Save profit for expansion

xxiii. Accept and face challenges

xxiv. Be hard working

$\mathrm{xxv}$. Become future oriented

xxvi. Be able to work under pressure

xxvii. Motivate others to achieve

xxviii. Demonstrate the drive to achieve

xxix. Take independent actions

xxx. Recognize business opportunities 


\section{International Journal of Science and Research (IJSR) \\ ISSN (Online): 2319-7064}

Index Copernicus Value (2013): 6.14 | Impact Factor (2014): 5.611

2) Ability to work extra hours was considered as an undesirable trait.

3) Entrepreneurs, Vocational Technical Teachers and Students differ significantly on the general characteristics that determine entrepreneurial potentials.

\section{Discussion of Findings}

The findings of this study with regards to the general characteristics that determine potential entrepreneur indicate that 30 personality potentials that VTTE students are expected to manifest were rated as very desirable. This finding conforms to the assertion of Carre and Thurik (2002) who confirmed that entrepreneurship is essentially a behavioural characteristic of a person. Entrepreneurs and potential entrepreneurs like VTTE students may exhibit it only during a certain phase of their career or with reference to certain activities. However, entrepreneurs, vocational technical teachers and students themselves scored work extra hours as an undesirable trait. Perhaps this is to be expected since some practicing entrepreneurs who worked extra hours developed early symptoms of stressors due to hassle (Obi \& Obi, 2007). The Obi's were merely reechoing the experience of techno entrepreneurs by lending credence to this result.

The significant difference in the mean responses of the respondents on the general characteristics that determine potential entrepreneur as shown in the findings of hypothesis number 1 is consistent with Kolo (2004) who said that individual differences accounts for personality traits such as confidence, intelligence and loyalty. These traits are the qualities a teacher should stimulate in individual students for each to be able to start up an enterprise after graduation. The statistical difference might have been due to students' inexperience as reflected in THDS test.

\section{Conclusion}

VTTE students have a wide range of potentials to be explored. It will require a careful and diligent teacher to stimulate students to bring out these potentials. The 30 general determinants of entrepreneurial potentials identified in this study are by no means exhaustive. In order to generate additional determinants, this study should be replicated.

The ability to work extra hours was considered unacceptable in this study. However, this finding does not portray the inability to work hard by entrepreneurs and potential entrepreneurs as desirable. All entrepreneurs should work hard in order to achieve the desired goal. But working extra hours is likely to result into early stressor.

\section{Recommendations}

The following recommendations were made based on the findings of the study:

1) Vocational Technical Teachers should encourage and stimulate students to exude the gereral characteristic that makes a person potential entrepreneur.

2) Potential entrepreneur should be discouraged to work extra hours which may lead to unwanted stressors.

\section{References}

[1] Baron, J. \& Frisch, D. (1994). Ambiguous probabilities and the paradoxes of expected utility. In G. Wright \& P. Ayton, (Ed). Subjective Probabilities. Chichester: John Wiley and sons. 273 - 294.

[2] Carolyn, B. (2000). Entrepreneurial education teaching guide. Kaufman center for entrepreneurial clearing house on Entrepreneurship Education (CELCEE) Kansas City Digest. Retrieved from http//www.celcee.educ.

[3] Carree, M. \& Thurik, A. R. (2002). The impact of entrepreneurship on economic growth. In A. Zoltan \& D. B. Audretsch (2003). International Handbook of entrepreneurship Research. Boston, Dordrecht: Kluwer academic publishres.

[4] Casson, M. (2003). The entrepreneur: An Economic Theory, second edition. UK: Edward Elgar publishing.

[5] Dejadin, M. (2000). Entrepreneurship and economic growth: an obvious conjunction? An introductive survey to specc topics. Belgium: Crew, Faculty of Economic and social sciences, University of Namur.

[6] Fayolle, A. \& Lyon, M. E. (2004). Value creation in changing student state of mind behaviour: New research approaches to measure the effect of entrepreneurship education. Retrieved from www.epientrepreneurship.com

[7] Jovanovic, B. (1994). Firm formation with heterogeneous management and labour skills. Small Business Economics. 6(3), 185 - 193.

[8] Kolo, M. (2004). Programme delivery in brief . Kaduna: National Directorate for Employment.

[9] Lynch, R. L. (2000). High school career and technical education for the first decade of the $21^{\text {st }}$ century university Georgia. Journal of Vocational Education Research. 25(2), 98-105.

[10] McCIelland, D. (1961). The achieving society. Princeton, N. J.: Van Nostrand.

[11] Nel, J. D. \& Badenhorst, W. J. A. (2003). Small business book and entrepreneurship. Retrieved from http://www.thinkinglike.com

[12] Obi, I. \& Obi, E. (2007). Stress Management. Awka, Nigeria: Sunrise Publications. 